\title{
School completion in urban Latin America: The voices of young people from an informal settlement
}

\author{
Ann Mitchell, Pablo Del Monte \& Séverine Deneulin
}

\begin{abstract}
Despite progress in improving secondary school completion in Latin America, a high proportion of young people from urban marginalised neighbourhoods continue to drop out. On the basis of in-depth interviews with young people in an informal settlement of the City of Buenos Aires, the paper aims to broaden the understanding of the processes that lead to school dropout in these neighbourhoods. It does so by examining what young people value being and doing, and how they interpret the value of secondary school in their own lives and contexts. The results point to the critical importance of the family in young peoples' processes of reasoning and decisionmaking, the complex interaction between capabilities, and the benefits of schools that provide social and emotional support to students and families. The paper argues that listening to the voices of young people can give significant insights for the design of policies to close the gap in education outcomes in segregated urban contexts.
\end{abstract}

Keywords: Education, equality, urban marginality, Latin America, capability approach

\section{Introduction}

During the past twenty-five years Latin America has made notable progress in education (Rivas, 2015; Tedesco \& Lopez, 2004; UNESCO, 2014). Between 1990 and 2010 rates of school enrolment and graduation increased at all levels (Bassi, Busso \& Muñoz, 2013). At the primary and secondary school levels, inequality of access - measured by the gap in the rate of enrolment between the first and the fifth income quintiles - also narrowed in almost all countries (Cruces, García Domench \& Gasparini, 2011). The region, however, is far from achieving equality of opportunity in education. The socioeconomic circumstance of the household in which a child grows up continues to be a strong determinant of the likelihood of completing school at the expected age and having acquired the needed skills. Research has associated the fragmentation in education opportunities in Latin America with a rise in social segregation between public and 
private schools (Arcidiácono et al., 2014; Kessler, 2002), as well as increasing residential segregation (Katzman, 2001).

The City of Buenos Aires (CBA), ${ }^{1}$ which experienced a threefold rise in the share of the population living in informal settlements between 1990 and $2010,{ }^{2}$ is a relevant case for studying the obstacles to school completion in segregated neighbourhoods. The city's informal settlements (or villas ${ }^{3}$ ) face markedly inferior access to public services, problems of accessibility, insecurity, social isolation and environmental degradation that place constraints on the ability of residents to do well in health, education, work and other dimensions of life (Suarez, Mitchell \& Lépore, 2014). Only one out of four 18-year olds from the villas of the CBA has graduated from secondary school, compared with three out of four from the rest of the city (Mitchell \& Peregalli, 2014). The sharply lower rate of school completion within the city's informal settlements coincides with the findings from poor segregated urban communities in other contexts (Goldsmith \& Blakely, 2010; Katzman, 1997; Mayer \& Jencks, 1989). The literature provides evidence on the effects of the family (Ginther, Haveman \& Wolfe, 2000), the neighbourhood (Kling, Leibman \& Katz, 2007; Sampson, Morenoff \& Gannon-Rowley, 2002) and schools (Thrupp \& Lupton, 2006) on educational outcomes within poor urban neighbourhoods.

The Government of the CBA has introduced diverse policies to promote equality of opportunities in educational access, reducing drop-outs and educational outcomes. It has, for example, introduced a school scholarship programme, which provides an annual grant targeted

\footnotetext{
${ }^{1}$ The CBA, the federal capital city, has a population of approximately 3 million, whereas the surrounding 24 municipalities that make up Greater Buenos Aires have a population of 14 million.

${ }^{2}$ The share rose from 1.8\% in 1990 to 5.7\% in 2010 (Dirección General de Estadística y Censo, 2010). ${ }^{3}$ Villas can be defined as informal urbanisations that have an irregular layout, accessed through narrow passageways with a high population density and self-made structures often several stories high (TECHO, 2016). The term has both negative and positive connotations, depending on the context and speaker. We use the term here because that is the way in which the young people we interviewed referred to their neighbourhood.
} 
to the most economically and socially vulnerable groups. Eight 'reinsertion' schools have been given greater flexibility to adapt course loads and curriculum to the specific context and needs of young people who did not complete secondary and have been out of the school system for at least two years (Cabado et al., 2010). Other education inclusion programmes include the provision of childcare for adolescent mothers and fathers, youth clubs, work internships, tutoring, summer schools, camping programmes and youth orchestras (Cabado et al., 2010). A current debate concerns whether or not schools should be located within informal neighbourhoods (to promote inclusion) or outside (to promote integration). While the subjective evaluation of these programmes by school directors, teachers and young people have been positive (Krichesky et al., 2011), current public policies are not sufficient to close the gap in the educational outcomes of the young people living in informal settlements (Mitchell \& Peregalli, 2014)

With the overall aim of contributing to the development of policies to improve educational outcomes in marginalised communities, the paper's objective is to broaden the understanding of the factors that lead to school dropout in marginalised urban neighbourhoods by taking, as a starting point, the views of young people themselves and by analysing what young people value being and doing, and what value they place on secondary school. The analysis is based on interviews with young people ages 15 to 24 who live in an informal settlement of the CBA. In the interviews we focused on two central questions: first, what do you value most in your life? and, second, what is for you the value of secondary school? The paper demonstrates insights into the causes of school dropout that can be gleaned from narratives on what young people value most, both within school and in other aspects of their lives. 
The paper uses Sen's capability approach as the theoretical framework. This normative perspective assesses situations not in the space of incomes or resources but in the space of 'functionings' and 'capabilities', that is, what people are able to be and do, and conceives people as agents of their own lives and not passive recipients of policies (Nussbaum 2000, 2011; Sen, 1980, 1992, 1999, 2009, 2017; UNDP 2016). Over the last decade the capability approach has acquired greater prominence in education research (Hart, 2012a, 2012b; Hinchliffe \& Terzi, 2009; Otto, 2015; Saito, 2003; Tikly \& Barrett, 2011; Vaughan, Unterhalter \& Walker, 2007).

The paper is structured as follows. The second section discusses the relevance of using the capabilities approach to analyse school drop out in urban marginalised communities. The third section describes the research methodology. The fourth section presents the qualitative analysis. It underlines the critical importance of the family in young peoples' processes of reasoning and decision-making, the complex interaction between functionings and the benefits of schools that provide social and emotional support to students and families. The paper ends with a summary of the main conclusions and discussion of some policy implications, namely the need for greater inter-sectorial articulation between schools, community organisations and local public institutions, and more integral policies that go beyond educational provision.

\section{Education inequality and Sen's capability approach}

Sen introduced his concept of 'capability' in the context of the question of 'equality of what?' (Sen, 1980). If we are concerned about equality, Sen asked, what is the most adequate space to think about equality and capture information about it? The capability approach is a framework to conceptualise inequality in a new light (Sen, 1992), not from the perspective of resources or incomes but of freedom, or what Sen coined as 'capability' - or 'a person's ability to do valuable acts or reach valuable states of being' (Sen 1993, p.30). From this perspective a young 
person's life is not considered only for its productive potential, or as a bearer of individual rights, but also, and foremost, as a free person whose freedom is constituted by his or her ability to do or be what he or she has reason to value (Hart, 2012a, 2012b; Robeyns, 2006; Sen, 1997; Unterhalter, 2009; Walker \& Unterhalter, 2007). ${ }^{4}$

The capability approach makes a clear distinction between resources on the one hand and valuable beings and doings, or 'functionings', on the other. Individual characteristics, context, institutions and relationships are critical for determining how resources are converted into wellbeing opportunities (capabilities) and wellbeing achievements (functionings) (Sen, 1992, 1999). As Hart states: 'The capability approach recognizes that not all individuals will participate or benefit from education in the same way, nor are able to convert the resources afforded by education to generate the same or similar advantages in life' (2012b, p. 276). The policy challenge is therefore not only about providing educational resources but about how to convert them into access to valuable beings and doings.

Another reason for using the capability approach to analyse education inequality in an urban context is that it allows for a dynamic understanding of disadvantage. In their study on disadvantage from a capability perspective, Wolff \& De-Shalit (2007) introduced the terminology 'corrosive disadvantages' and 'fertile capabilities' to capture how disadvantages in one area are likely to impact on disadvantage in another, or how seized opportunity in one area is likely to lead to the opening of further opportunities. This concept is particularly relevant in the context of marginalised urban communities where residents face an accumulation, or 'clustering', of disadvantages (Suarez et al., 2014).

\footnotetext{
${ }^{4}$ For a more general discussion on the role of values in education, and what valuable beings and doings education should foster as part of its contribution to human flourishing, see Brighouse, Ladd, Loeb \& Swift (2016).
} 
Finally, according to this normative framework, the process of expanding individual freedoms depends not only on the broadening of functionings or capabilities but also on agency, defined as 'the freedom to achieve whatever the person, as a responsible agent, decides he or she should achieve' (Sen 1985, p. 203-204). In other words, it is important to consider the ability of young people to be the author of their own lives (Hart, Biggeri \& Babic, 2014; Otto \& Ziegler 2010; Tikly 2014). ${ }^{5}$

\section{Methodology}

The qualitative analysis is based on interviews carried out between April and June 2015 in one of the CBA's oldest informal settlements. Its origin dates back to the 1940s when workers who migrated to the city to find employment in the expanding industrial sector were forced to build informal housing on unoccupied lands. The neighbourhood was populated first by domestic migrants and then increasingly by immigrants from Bolivia and Paraguay. While the neighbourhood was nearly eradicated during the military regime of 1976, the pace of population growth accelerated during the past three decades. Today it is one of the city's largest villas in terms of area (comprising approximately 30 blocks) and its population is estimated to range from 25 to 60 thousand. ${ }^{6}$ It is also known to be one of the City's most insecure neighbourhoods and an important centre of the drug trade (Di Nicola, 2015).

The methodology of qualitative analysis draws on the principles of experience-centred narrative research (Squire, 2013). Storytelling is an 'essential human activity’ (Phelps, 2006, p. 105; see also Ricoeur 1984, p. 52), whereby individuals give meaning to and make sense of their experiences (Andrews, Squire \& Tamboukou, 2013). Following the argument advanced

\footnotetext{
${ }^{5}$ See also the European project 'Empowering the Young for the Common Good' which seeks to draw insights for EU youth policies on the basis of young people's agency, http://www.society-youth.eu.

${ }^{6}$ The lower estimate is based on the 2010 Census (Dirección General de Estadística y Censo, 2010) and the higher estimate on the NGO TECHO's informal settlements survey (TECHO, 2016).
} 
by Polkinghorne (2007, p. 479) that 'storied texts serve as evidence for personal meaning', we consider that in producing narratives participants select and interpret particular events through the mediation of language and in dialogue with the researcher. We do not consider the narratives to be objective representations of experience, but rather to be a means of understanding how and why young people make certain decisions and pursue different goals.

We interviewed a total of 20 young people, ranging in age from 14 to 24 years. The participants were selected using a purposive sampling method in which we sought to include approximately the same number of men and women and a range of education trajectories. In order to elicit stories about significant "turning point moments' ${ }^{77}$ related to the focus of this research, we included in the sample ten participants who had never left school, five who had left school but later returned and five who had dropped out without finishing. A total of seven of the interviews were conducted with students who attend a newly opened secondary school linked to the local Catholic parish, which is the only secondary school located within the informal settlement.

The interviews ${ }^{8}$ centred on two main questions: first, what do you value most in your life? and, second, what is for you the value of secondary school? An effort was made to let the young people express their ideas and share stories about their lives with limited guidance, so as to allow them to reflect on the meanings of the experiences they described and take an active role in the interview. ${ }^{9}$ The duration of the interviews ranged from 25 to 90 minutes.

\footnotetext{
${ }^{7}$ We consider "turning point moments" to be structuring conditions of the narratives (Denzin, 1989, p. 22).

${ }^{8}$ The interviews were carried out by the Buenos Aires based authors and conducted under the University of Bath Research Ethics guidelines. Before the interviews, participants were briefed about the aims and use of the findings involved in the research. Interviewees gave their informed consent before participating and had the right to withdraw from the interview at any time. The names of the participants have been changed to protect their anonymity.

${ }^{9}$ This practice in narrative research aims to give participants the time to 'bring notice to the layers of meaning that are present outside of awareness' (Polkinghorne, 2007, p. 480).
} 
We transcribed the interviews and carried out an initial analysis using the qualitative data software NVIVO. At this stage, using the concepts of the capabilities approach, we identified the beings and doings that the participants value most according to their narratives and the corresponding texts. We also selected the texts that made reference to the value of school. From these initial groups of texts, we selected for further analysis the narratives that provided the richest details, most revealing descriptions and a diversity of situations.

\section{Young people's life stories in an urban informal settlement}

The qualitative analysis is divided into two parts. The first identifies some functionings, or 'beings and doings', which young people value in their lives and analyses the relationship between them. ${ }^{10}$ Then we analyse how young people interpret the value of secondary education in their own lives and contexts.

\subsection{Beings and doings young people value}

We asked participants what was most important to them in their current and everyday lives. Although the question was vague, the answers were precise and often stated with confidence. We focus on the three 'beings and doings' that were most common and emphasised in the narratives: being a daughter or son, being on the street, and working.

\subsubsection{Being a daughter or son}

Within family relationships, young people can be sons and daughters, fathers and mothers, or brothers and sisters, but it was the functioning of being a son or a daughter that came up most

\footnotetext{
${ }^{10}$ We do not take a position with regard to the extent to which what young people value may be the object of adaptive preferences (Lessman, 2009; Unterhalter, 2007), that is, we do not engage in a critical deliberative exercise with young people about what they value and the robustness of their reasons for valuing one 'being' or 'doing' over another.
} 
often in the interviews. What Julia valued most was the unconditional love and care she received from her mother:

My mother is one of the most important persons in my life because she is someone that I have always counted on. (...) Even though I was consuming drugs, stealing, dirty, drunk, she never left me in the street. She always received me with open arms, gave me a meal, a bed, clean clothes. That's something that I realize now, I didn't value it when I was consuming drugs (...) I didn't want to see it. (Julia, age 20, dropped out of school)

To conceive of 'being a son or a daughter' as a functioning may seem counter-intuitive. ${ }^{11}$ However, for the young people we interviewed, being a son or a daughter is neither a biological relationship nor a passive position of receiving care or shelter. It is an active role in a relationship that is reciprocal, albeit uneven. There is also a choice involved in being a son or a daughter, as some had chosen to leave their home and others to become sons and daughters of adults other than their biological parents, such as a grandmother, an uncle or a priest.

The narratives included references to diverse family problems, including lack of basic subsistence, drug and alcohol addictions, absent mothers or fathers and family members who were in prison or involved in delinquent activities. In some cases, these situations limited the young peoples' ability to be a son or daughter. Antonia explains below how her mother's addiction to drugs had kept her from fulfilling her role as a mother and how her own life had changed after her mother had stopped taking drugs:

What changed a lot was that I used to see my mother really bad and now she's well. She wasn't a mother for me before, she only wanted to get drugged and nothing else. Now

\footnotetext{
${ }^{11}$ Sen refutes the idea that material functionings are necessarily more valuable than nonmaterial ones and states that 'any achievement that is rooted in the life that one leads (or can lead), rather than arising from other objectives, does have a claim to being directly relevant to one's standard of living' (Sen,1986, p. 36).
} 
she pays attention to what I do. We do fight a lot, but she cares for what I need and is best for me. (Antonia, age 14, at school)

In situations in which the young people had to care for their brothers and sisters, the functioning of being a son or daughter became ambiguous, as they had assumed the role of mother or father, as is the case of Alma:

She [her mother] began to drink and go out a lot and I had to stay at home with my sisters because my brother also went out dancing. And then one day I got tired and told her: 'I'm fed up. If you keep going out dancing and drinking I'm leaving the house'. And then she started to come to church more often (...) I don't know what happened, she started to listen to me, about what she should do, what I shouldn't do, and everything changed. (Alma, age 14, at school)

By threatening to leave home Alma reclaimed her functioning of being a daughter and her mother's functioning of being a mother. In order to sustain the functioning of 'being a son or a daughter', some participants had to take on excessive duties and responsibilities, negatively affecting their schooling trajectories.

\subsubsection{Being on the street}

Some of the stories told by the participants highlighted periods in their lives that had taken place on the street. Pedro associated being on the street with having freedom. He described a hot summer evening at age 13 when he had stayed out late at night selling things on the street to make enough money to buy a fan for his family. In the following passage, he describes how he felt:

My mother was waiting in front of my house, and when she saw that I had brought a fan she laughed and cried. (...) We were together, very happy. That was an achievement I had forgotten. I hadn't spoken about it in a long time. Because, the truth is that it hurts all the things that I lost [working in the streets]. I was the eldest, I had to work. I learned 
more from the street than from education (...). I'm the only one of my siblings that had freedom at such a young age. I was thirteen. I had freedom because I worked. (Pedro, age 22, dropped out of school).

While this account makes clear that Pedro valued the freedom he experienced on the street, it also shows that it was painful for him to remember what he had lost by working on the street from such a young age.

What another participant, Marcos, emphasised most about having freedom on the streets, was the ability to buy goods, become self-sufficient and help care for his siblings:

As I grew up I realized that everyone progressed and that my house was still a wooden shack, and I made the decision to start to rob, and that's how everything began. Before I started stealing I had to meet people that did that. I had to become one of them, and so I had to be mean, to impose respect. (...) That's how I began, and once my house was fine and we didn't need anything else I kept doing it because I had gained a taste for it. I liked it. I liked the easy money. I liked to have everything in the moment, and that was the easiest way to get money. (Marcos, age 24, dropped out of school)

To be successful on the street, Marcos first needed to learn from more experienced peers how to gain respect and to steal. ${ }^{12}$ Once Marcos had gained experience, he learned that stealing also brought him the adrenaline and excitement of getting a lot of money all at once (the 'easy money'), making the activity hard to quit.

It is relevant to identify some common characteristics of the two young men's experiences on the streets. First, in both cases the desire to provide for their families seems to have been the initial motivation to leave school and be on the streets, demonstrating the interaction between these two valued functionings. Second, once they had gained experience

\footnotetext{
${ }^{12}$ The influence of peers on criminal behaviour in disadvantaged neighbourhoods has been demonstrated both through qualitative (Harding, 2009) and quantitative (Damm \& Dustmann, 2014) research.
} 
on the street, both men came to value some aspect of life on the street (a feeling of freedom, a taste for getting the 'easy money', recognition from peers). They felt they were progressing, which made it more difficult for them to return to school. Finally, the contact with the trade and use of drugs led both individuals to become addicted to drugs.

Almost all of the young people we interviewed made references to drugs, whether in describing their own experiences, or talking about the sale of drugs in their neighbourhood, or relating family members' or friends' problems of addictions. Drugs were used as a category, or dividing line, which separates lives ruined by addictions from the lives the young people aspired to have, a finding that is consistent with evidence on the problem of drug addictions in this context. $^{13}$

\subsubsection{Working}

Although child labour is illegal in Argentina-according to Law 26.390 children under the age of 16 cannot sign work contracts - many of the participants mentioned having worked, for example, in illegal textile factories, a restaurant or a hair salon. In nearly all cases the job was low quality and informal. ${ }^{14}$ Daniel, for example, described working in his family's trash collection business: ${ }^{15}$

The cart wears you out. It is not any easy thing. You have to go out and collect the trash, unload and the next day you are destroyed. Many times I cut myself, my arm. When you throw the glass in the cart it breaks and you get cut ugly. (Daniel, age 18, dropped out of school)

\footnotetext{
${ }^{13}$ The results of a civil society organisation survey showed that 6 out of 10 organisation leaders considered drug addiction to be the principal problem in this neighbourhood (Mitchell, 2012).

${ }^{14}$ Informal jobs tend to be unskilled, low productivity, small scale, unregistered and family based (Gasparini \& Tornarolli, 2009).

${ }^{15}$ According to the Argentine Federation of trash collectors and recyclers, 200 thousand 'cartoneros' (informal trash collectors) gather and recycle daily around 10 thousand tons of waste. See http://facyr.org.ar/.
} 
He hated that job so much that he had decided to steal instead, as he found it to be more profitable, less exhausting and less risky to his health. Eventually, however, when given the opportunity to work in a formal job with his brother who worked as an electrician, he decided to quit stealing and to work. When asked whether he earned more working or stealing, he responded: 'Working, because money that comes easy goes easy. As it comes it goes. You end up buying drugs and that's it. [Now that] I break my back working I don't want to spend my money on drugs. I invest it. The day before yesterday I bought a fridge'.

It is interesting to note that while Daniel was stealing he had time to go to school, although he was not a good student and his interest in school was not related to becoming educated but rather to the fun he had there (meeting girls, gaining respect from other students). He had to quit school when he started the formal job because the working hours did not permit it. All three types of work (trash collecting, stealing, or the formal job) gave him the money he needed to help provide for his family. But the work that he valued the most was the formal job, which gave him stable hours and a stable income.

The capability approach has focused attention on the value of work, not just as a means for earning income and satisfying material needs but also its intrinsic benefits (Bonvin, 2012; Egdell \& Mcquaid, 2016; OPHI-CAF, 2016). Work, it is argued, can provide a sense of selfrespect and opportunity for personal fulfilment. The value of work depends not only on the quantity but also the quality of work in terms of job security, stability, occupational risk, legal protection, hours and opportunities for developing skills.

Daniel's account of his different job experiences underscores the value of formal work in this context, which goes beyond the purpose of satisfying material needs. The benefit of his formal job appears to be associated with the intrinsic value of the toil on the job, which, in a 
sense, alters the value of the money earned. We will return to this result in the analysis of the value of secondary education.

\subsection{The value of secondary schooling}

When we asked the young people what the value of secondary education was for them, most emphasised the instrumental value, that is, the need to finish secondary school in order to find a job, earn money and care for their family. Some participants said they wanted to finish high school so that one day they could move out of the villa.

The participants often associated the value of secondary education with the desire to fulfil their parents' expectations or the encouragement they had received from another adult (for example, an aunt or a grandparent). In the following narrative Raul described how his family encouraged him to complete school:

Most people encourage me to study, to finish high school. And others who haven't finished also tell me: 'study, study, be someone in life'. They also give themselves as an example 'don't be like me, working in this place, we want you to be sitting in an office, so do finish high school'. They more or less say 'don't be like me'. (Raul, age 16 , in school)

It is relevant to note that Raul emphasised how people encourage him both to obtain an occupation different from his family members' (in an office) and to work in a different location (outside of the villa).

Victoria said that she was motivated to finish school because she did not want her own life to turn out like her mother's:

She [her mother] never had the opportunity to study and now she is having a difficult time. If she had studied and gotten a degree she would not be working as a maid now, 
she would have more time and she would not be so tired when she gets home. (Victoria, age 17 , in school)

Although only one out of four adults over age 24 in the villas has completed secondary school (Mitchell \& Peregalli, 2014), there is strong evidence that parents encourage their children to finish school and aspire to a better life. In Argentina education has been a principal means for improving socioeconomic status and it continues to be highly valued by all sectors of society, even in the most disadvantaged neighbourhoods. What is less clear is the extent to which education truly enables upward mobility in this context. A recent study, which compares the quality of the occupations inside and outside the city's informal settlements, concluded that unlike the rest of the city, in the villas education is not a decisive factor in determining labour market outcomes (Lépore \& Simpson, 2016). The majority of the young people we interviewed, however, spoke of the need to get a high school diploma in order to get a good quality job.

While the instrumental value of school was the primary motivation for attending school, a few participants mentioned the rewards of gaining knowledge and putting it into practice. For example, a young man spoke of how he valued the practical computer skills he had learned in his information technology class. Maria described how she had learned to express herself through writing:

In language we write a lot and I like to write. I wrote many times for the [school's] newspaper. They told me that I write very well. I'm not very good at expressing myself speaking, but I can do it writing. Sometimes when I'm feeling sad I write'. (Maria, age 15 , in school).

The experience of learning in this case had an immediate effect by providing Maria with skills that she could use in her everyday life, such as the ability to communicate with others and manage her feelings. Maria went on to describe how she felt when her music teacher, who played in a rock band, told her that he was going to use something she had written in a song: 
'There are times when I feel that I am not worth anything, but when he told me that, I realized that, yes, I am good for something, I have value'. In this case the music teacher had helped raise Maria's self-esteem by connecting with his student in a way that went beyond his role as a teacher, what Meo, Dabenigno and Ryan (2012) call 'amplified teacher professional identity'.

School is also valued as a place for bonding, making friends and establishing relationships. Although none of the young people interviewed mentioned friendship as what they valued most, they saw spending time with peers as an important dimension of going to school, which is consistent with previous research (Smyth et al. 2004).

Many of the participants valued school for the different forms of support it provides, including being listened to or having a (physical) place they can go to get away from a conflictive family relationship or inadequate housing. What stands out as an important positive characteristic of the school linked to the Catholic parish located in the villa is the emotional support provided by teachers and counsellors. Antonia described how her teachers took the time to listen to her and even to talk with her parents:

When we feel bad, or aren't well, or fight with our mother or with anyone, or a relative passes away, they take time away from the things that they have to do to listen to us, to give us advice. They worry about how we feel and what happens to us. They have their own personal lives, their families and in spite of everything they still care about us. It's not like in the other school, where you tell them what is going on and they say 'well, you'll work it out'. Here they support you, they help, talk with your family, find time to talk to you (Antonia, age 14, in school).

Maria, who attends the same school, explained: 'The professors and counsellors were always with me when I needed them (...) They taught me tons of things. They taught me to believe in myself, to get ahead, to respect my classmates and teachers, to concentrate on studying'. 
The critical role of teachers in providing emotional support, concern and respect for students reinforces the findings of previous research, which showed that this aspect of school is particularly important for students from marginalised communities (Binstock \& Cerruti, 2005). These narratives, moreover, illustrate how the school linked to the Catholic parish in the villa supports students within the social context of their community. By helping to sustain the functioning of being a son or daughter, the school also helps to promote and enable the capability of being a student. Both capabilities become mutually fertile.

The young people's narratives on the value of school suggest, therefore, that school dropout is not associated with a low perceived value of education nor a lack of encouragement from parents. Instead, as described in the last section, the decision to leave school and low performance at school, tend to be related to the functioning of being a son or daughter; the need to help provide for their families' material needs and complex family situations, in some cases related to addictions to drugs.

\section{Conclusions}

This paper has sought to broaden the understanding of the factors that lead to secondary school dropout in marginalised urban neighbourhoods by listening to the voices of young people themselves. The mapping of young people's 'evaluative spaces' led to the identification of three valued functionings: being a son or daughter, being on the streets and working. The narratives on the value of education centred on the instrumental value of secondary school, the desire to fulfil parents' expectations and the role of teachers in providing support to students and families. The paper makes four main contributions to understanding the process of school dropout.

First, consistent with the prevailing knowledge on educational challenges in urban marginalised communities, the family is a critical determinant of schooling outcomes. However, 
while previous research has emphasised the importance of the economic situation of the household and the role of parents in setting an example and defining values and expectations with regard to school, what was most evident in the interviews was the young people's desire to protect and provide for their families. Even in the most complex and conflictive family situations, the desire to care for younger siblings or their own child appeared as a principal motivation in the processes of reasoning and decision-making. The narratives of two young men who ended up on the streets, in delinquency and eventually addicted to drugs, illustrated that the initial motivation for 'being on the street' was to help satisfy their families' needs.

Second, the accumulation of deprivations in informal neighbourhoods creates a complex and dynamic interaction between capabilities. The method of narrative analysis, which seeks to elicit stories about significant life experiences, proved to be an effective method for mapping the interconnection between capabilities. The value of school was defined in relation to the value of work in the future. The functioning of being a son or daughter was found to be both fertile to the functioning of going to school (when it meant having a home, receiving care from parents, etc.) and corrosive (when it demanded excessive responsibilities of caring for siblings or sustaining the family).

Third, the young people expressed with clarity what they value most in their lives and the reasons for their own decisions regarding family, work, school or being on the street. In some of the narratives the young people described their resistance to family and school obligations. Opting out of family or school was presented as a feasible choice. Although in these cases, the young peoples' decisions should not be construed as being positive as they were often made in reaction to adverse conditions, they were not simply reproducing what was expected of them within their immediate context. 
Fourth, the narratives highlighted that schools also have an intermediate value as institutions rooted within a community. Schools and teachers provide emotional support, social assistance, aid in resolution of family conflicts and spaces for socialisation. These aspects of schools were mentioned as important in the lives of young people and instrumental in defining schooling trajectories. In some cases this aspect of school provides a safety net, preventing students from dropping out.

These results provide some lessons for the design of public policies to foster school completion in urban marginalised neighbourhoods. First, more relevant than the question of whether or not schools should be located inside or outside of informal settlements, what is critically important is that schools provide social and emotional support to students from disadvantaged families. While the plurality of functions that schools must take on can potentially create tensions within educational institutions (regarding schools' ethos and the intensification of teachers' workloads, for example), it is an effective way to promote school completion in poor urban neighbourhoods. The inter-sectorial articulation between schools, community organisations and local public institutions can help to achieve this goal without overburdening teachers, as some preliminary programme evaluations suggest (Krichesky et al., 2011).

Second, there is a need to integrate educational policies with broader social policies in informal settlements. Policies to satisfy material needs, improve public services and guarantee access to childcare can help families to produce the 'fertile capabilities' that will enable young people to be students. There is also a need to bolster government drug prevention and treatment programmes, and foster greater articulation with local organisations, which have taken on a central role in addressing this problem in marginalised neighbourhoods (Mitchell, 2012). Finally, the recent trend toward the introduction of integrated anti-poverty programmes that 
provide multidimensional social assistance to the most vulnerable households (Barrientos \& Santibáñez, 2009; Barrientos, 2010) is a relevant area for continued research and evaluation.

Acknowledgements: We thank Gustavo Carrara for facilitating the interviews, and the young people who gave their time to participate in the study. We also thank the anonymous reviewers for their useful comments. 


\section{References}

Andrews, M., Squire, C. \& Tamboukou, M. (Eds.). (2013). Doing narrative research. 2nd ed. London: Sage Publications.

Arcidiácono, M., Cruces, G., Gasparini, L., Jaume, D., Serio, M. \& Vázquez, E. (2014). La segregación escolar público-privada en América Latina. Serie Políticas Sociales de la CEPAL, 195, 1-37.

Barrientos, A. (2010). Protecting capability, eradicating extreme poverty: Chile Solidario and the future of social protection. Journal of Human Development and Capabilities, 11(4), 579597.

Barrientos, A. \& Santibáñez, C. (2009). New forms of social assistance and the evolution of social protection in Latin America. Journal of Latin American Studies, 41(1), 1-26.

Bassi, M., Busso, M. \& Muñoz, J. (2013). Is the glass half empty or halffull? School enrollment, graduation, and dropout rates in Latin America (Working Paper No. 462). Washington, DC: Inter-American Development Bank.

Binstock, G. \& Cerruti, M. (2005). Carreras truncadas. El abandono escolar en el nivel medio en la Argentina. Buenos Aires: UNICEF.

Bonvin, J. M. (2012). Individual working lives and collective action. An introduction to capability for work and capability for voice. Transfer: European Review of Labour and Research, 18(1), 9-18.

Brighouse, H., Ladd, H., Loeb, S. \& Swift, A. (2016). Educational good and values: A framework for decision-makers. Theory and Research in Education 14(1), 3-25.

Cabado, G., Falcone, J., Greco, M., Krichesky, M., Quintero, S., Saguier, V. \& Zanelli, M. (2010). Políticas de inclusión y gestión educativa en escuelas medias en contextos de alta vulnerabilidad. Relación entre políticas y prácticas. Buenos Aires: Dirección de investigación y estadística. Ministerio de Educación, Gobierno de la Ciudad de Buenos Aires. Retrieved from:http://www.buenosaires.gob.ar/sites/gcaba/files/2010politicas_de_inclusion_y_gestion_e ducativa_en_escuelas_medias_en_contextos_de_alta_vulnerabilidad._relacion_entre_politicas _y_practicas_0_1.pdf

Cruces, G., García Domench, C. \& Gasparini, L. (2011). Inequality in education: Evidence for Latin America (Working Paper No. 2011/93). Helsinki: UN-WIDER.

Damm, A. P. \& Dustmann, C. (2014). Does Growing Up in a High Crime Neighborhood Affect Youth Criminal Behavior? The American Economic Review, 104 (6), 1806-1832.

Denzin, N. (1989) Interpretive Biography. New York: Sage.

Di Nicola, G. (2015). Submundo narco: cómo operan las bandas en la villa 1-11-14. La Nación, 9 June. Retrieved from http://www.lanacion.com.ar/1800074-submundo-narco-como-operanlas-bandas-en-la-villa-1-11-14

Dirección General de Estadística y Censo. (2010). Resultados provisionales del censo nacional de población, hogares y vivienda 2010 en la Ciudad de Buenos Aires. Buenos Aires: Gobierno de la Ciudad de Buenos Aires. Retrieved from http://www.estadisticaciudad.gob.ar/eyc/wpcontent/uploads/2015/07/resultados_provisionales _censo_2010.pd 
Egdell, V. \& Mcquaid, R. (2016). Supporting disadvantaged young people into work: Insights from the capability approach. Social Policy \& Administration, 50(1), 1-18.

Gasparini, L. \& Tornarolli, L. (2009). Labor Informality in Latin America and the Caribbean: Patterns and Trends from Household Survey Microdata. Desarrollo y Sociedad, $1^{\text {st }}$ semester, 13-80.

Ginther, D., Haveman, R. \& Wolfe, B. (2000). Neighborhood Attributes as Determinants of Children's Outcomes: How Robust Are the Relationships? Journal of Human Resources, 35 (4), 603-642.

Goldsmith, W.W. \& Blakely, E.J. (2010). Separate societies: Poverty and inequality in U.S. Cities. Philadelphia: Temple University Press.

Hart, C. (2012a). Aspirations, education and social justice: Applying Sen and Bourdieu. London: Bloomsbury.

Hart, C. (2012b). The capability approach and education. Cambridge Journal of Education 42(3), 275-283.

Harding, D. (2009). Violence, older peers, and the socialization of adolescent boys in disadvantaged neighborhoods. American Sociological Review, 74(3) 445-464.

Hart, C., Biggeri, M. \& Babic, B. (Eds.). (2014). Agency, participation in childhood and youth: International applications of the capability approach in schools and beyond, London: Bloomsbury

Hinchcliffe, G. \& Terzi, L. (2009). Capabilities and education. Studies in Philosophy of Education, 28, 387-390.

Kaztman, R. (2001). Seducidos y abandonados: El aislamiento social de los pobres urbanos. Revista de la CEPAL, 75, 171-189.

Katzman, R. (1997). Marginalidad e integración social en Uruguay. Revista de la CEPAL, 62, 91-116.

Kessler, G. (2002). La experiencia escolar fragmentada. Estudiantes y docentes en la escuela media de Buenos Aires. Buenos Aires: UNESCO.

Kling, J. R., Liebman, J. \& Katz, L. R. (2007). Experimental analysis of neighbourhood effects, Econometrica, 75(1), 83-119.

Krichesky, M., Cabado, G., Greco, M., Quintero, S., Saguier, V., Zanelli, M. \& Zapata, M. (2011). Formatos institucionales e inclusión educativa la zona sur de la Ciudad de Buenos Aires (2010-2011). Buenos Aires: Dirección operativa de investigación y estadística, Ministerio de Educación, Gobierno de la Ciudad de Buenos Aires. Retrieved from: http://www.buenosaires.gob.ar/sites/gcaba/files/2011_formatosinstitucionalesinclusioneducati va_0_0.pdf

Lépore, E. \& Simpson, S. (2017). Concentrated Poverty and Labour Markets: Youth Marginalization in Buenos Aires's Informal Settlements (Working Paper No. 2/2016). Retrieved from: http://www.uca.edu.ar/uca/common/grupo98/files/BASSP02161.pdf

Lessman, O. (2009). Capability and learning to choose. Studies in Philosophy and Education, $28,449-460$. 
Mayer, S. \& Jencks, C. (1989). Growing up in poor neighborhoods: How much does it matter? Science, New Series 243(4897), 1441-1445.

Meo, A., Dabenigno, V. \& Ryan, M. (2012, July). Identidades laborales docentes en una Escuela de Reingreso de la Ciudad de Buenos Aires. Paper presented at IX Seminario de la Red Estrado: Políticas educativas en América Latina. Praxis docente y transformación social, Santiago, Chile.

Mitchell, A. (2012). Las organizaciones de la sociedad civil en las villas de Bajo Flores y Barracas. En Lépore, E., Lépore, S., Mitchell, A., Macció, J. \& Rivero, E. Capacidades de desarrollo y sociedad civil en las villas de la ciudad. Buenos Aires: ENDUC.

Mitchell, A. \& Peregalli, A. (2014). Inclusión educativa: Evidencias y desafíos en las villas de la ciudad. In Suarez, A.L., Mitchell, A. \& Lépore, E. (Eds.) Las villas de la Ciudad de Buenos Aires: Territorios frágiles de inclusión social. Buenos Aires: Educa, 59-94.

Nussbaum, M. (2000). Women and human development. Cambridge, MA: Harvard University Press.

Nussbaum, M. (2011). Creating capabilities: The human development project. Cambridge, MA: Harvard University Press.

Otto, H-U. (Ed.). (2015). Facing trajectories from school to work: Towards a capabilityfriendly youth policy in Europe. Cham: Springer.

Otto, H-U. \& Ziegler, O. (2010). Education, welfare and the capabilities approach: A European perspective. Opladen: Barbara Budrich.

Oxford Poverty \& Human Development Initiative \& Corporación Andina de Fomento (2016). Las dimensiones faltantes en la medición de la pobreza. Bogotá: Centro para el Desarrollo Humano Centro Lyra; Centro para el Desarrollo Humano IERU; Corporación Andina de Fomento; Oxford Poverty \& Human Development Initiative.

Phelps, T. G. (2006). Narrative capability: Telling stories in the search for justice. In Deneulin, S., Sagovsky, N. \& Nebel, M. (Eds.). Transforming unjust structures. Dordrecht: Springer, 105120.

Polkinghorne, D. E. (2007). Validity issues in narrative research. Qualitative inquiry, 13(4), 471-486.

Rivas, A. (2015). América Latina después de las PISA: Lecciones aprendidas de la educación en siete países (2000-2015). Buenos Aires: CIPPEC-Natura-Instituto Natura.

Ricoeur, P. (1984). Time and narrative. Chicago: Chicago University Press.

Robeyns, I. (2006). Three models of education: Rights, capabilities and human capital. Theory and Research in Education, 4(1), 69-84.

Saito, M. (2003). Amartya Sen's capability approach to education: A critical exploration. Journal of Philosophy of Education, 37(1), 17-34.

Sampson, R. J., Morenoff, J.D. \& Gannon-Rowley, T. (2002). Neighborhood Effects: Social Processes and New Directions in Research. Annual Review of Sociology, 28, 443-478

Sen, A. (1980). Equality of what? In S. McMurrin (Ed.) Tanner lectures on human values (pp. 97-220). Cambridge: Cambridge University Press. Retrieved from http://www.ophi.org.uk/wpcontent/uploads/Sen-1979_Equality-of-What.pdf 
Sen, A. (1985). Well-being, agency and freedom: The Dewey lectures 1984. The Journal of Philosophy, 82(4), 169-221.

Sen, A. (1986). The Standard of Living. In McMurrin, S. M. (Ed.) Tanner Lectures on Human Values. Cambridge: Cambridge University Press. Retrieved from: http://tannerlectures.utah.edu/_documents/a-to-z/s/sen86.pdf

Sen, A. (1992). Inequality re-examined. Oxford: Clarendon Press.

Sen A. (1993). Capability and well-being. In Nussbaum M. \& Sen A. (Eds.) The quality of life. Oxford: Clarendon Press, 30-53.

Sen, A. (1997). Human capital and capability. World Development, 25(12), 1959-1961.

Sen, A. (1999). Development as freedom. Oxford: Oxford University Press.

Sen, A. (2009). The idea of justice. London: Allen Lane.

Sen, A. (2017). Collective choice and social welfare. $2^{\text {nd }}$ edition. London: Allen Lane.

Squire, C. (2013). Experience-centred and culturally-oriented approaches to narrative. In Andrews, M., Squire, C. \& Tamboukou, M. (Eds.). Doing narrative research. London: SAGE.

Smyth, J.,Hattam, R., with Cannon, J., Edwards, J., Wilson, N., \& Wurst, S. (2004). 'Dropping out,' drifting off, being excluded: Becoming somebody without school. New York: Peter Lang Publishing.

Suarez, A. L., Mitchell, A. \& Lepore, E. (Eds.). (2014). Las villas de la Ciudad de Buenos Aires. Territorios frágiles de inclusión social. Buenos Aires: Educa.

Tedesco, J. C. \& Lopez, N. (2004). Algunos dilemas de la educación secundaria en América Latina. Revista Iberoamericana sobre Calidad, Eficacia y Cambio en Educación, 2(1), 1-21.

TECHO Argentina (2016). Relevamiento de asentamientos informales 2016, Buenos Aires. Retrieved from http://relevamiento.techo.org.ar/

Thrupp, M. \& Lupton, R. (2006). Taking School Contexts More Seriously: The Social Justice Challenge. British Journal of Educational Studies, 54(3), 308-328.

Tikly, L. \& Barrett, A. (2011). Social justice, capabilities and the quality of education in low income countries, International Journal of Educational Development, 31(1), 3-14.

Tikly, L. (2014). Book Review: Agency and Participation in Childhood and Youth: International Applications of the Capability Approach in Schools and Beyond. Journal of Development Studies, 50 (11), 1587-1589.

Unterhalter, E. (2007). Gender, schooling and global social justice. London: Routledge.

Unterhalter, E. (2009). Education. In: Deneulin, S. \& Shahani, L. (Eds.), An Introduction to the Human Development and Capability Approach. London: Earthscan, 207-227.

Vaughan, R., Unterhalter, E., \& Walker, M. (2007). Capabilities approach to education - An overview. Prospero, 29, 13-21. 
Walker, M. \& Unterhalter, E. (Eds). (2007). Amartya Sen's capability approach and social justice in education. Basingstoke: Palgrave.

Wolff, J. \& De-Shalit, A. (2007). Disadvantage. Oxford: Oxford University Press.

UNDP (2016). Human Development Report 2016: Human Development for everyone. Retrieved from: http://hdr.undp.org/

UNESCO (2014). Situación educativa de América Latina y el Caribe: Hacia la educación de calidad para todos al 2015. Santiago: OREALC/UNESCO. 